\title{
Translating Near-Synonyms in the Quran: A Semantic Analysis of Three Near- Synonyms and their English Translations
}

\author{
ASMAA ALDUHAIM \\ Department of English, \\ Gulf University for Science \& Technology, Kuwait \\ Asmaa.alduhaim@hotmail.co.uk
}

\begin{abstract}
This paper aims to explore how translators translate both the connotative and denotative meanings of nearsynonyms from the Quran into English language. The article will shed light on the phenomenon of near-synonymy, as well as its connotative and denotative meanings and how the translator's background could have influenced their translation. There has been a dearth of attention on the translation of near-synonyms in the Quran; accordingly, this study examines three pairs of near-synonyms from the Quran and their particular translations in the following three English translations of the Quran itself: 1) The Koran Interpreted by Arberry; 2) The Quran: A New Translation by Abdel Haleem; and 3) The Sublime Quran by Bakhtiar. These translations were chosen due to the significant differences in style and translators' backgrounds. The analysis aims to highlight the difference in meaning of each pair of near-synonyms by distinguishing both their connotative and denotative meanings. This will be followed by an examination of the translations to recognise whether the near-synonyms were accurately translated in these given instances or lost some, or even all, of their meaning during the translation process and discuss if translator's background could have influence on it. Based on the discussion and analysis of these examples, it is evident that all three translations failed to distinguish between the pair of near-synonyms and to capture the accurate meaning throughout the Quran, leading to a semantic void. It is similarly clear that the linguistic complexity of the Holy Quran has created a challenging mission for translators, which has ultimately led to loss of accuracy and meaning. The results have shown that each translator chose their own approach based on their translational goal or their educational and personal backgrounds.
\end{abstract}

Keywords: Quran; Near-Synonyms; Quran Translation; Connotative Meaning; Equivalence

\section{INTRODUCTION}

According to Desilver (2013), about twenty-five per cent of the world's population is Muslim, and over eighty per cent of Muslims do not know Arabic, but rather use translated versions of the Quran. The Quran is one of the most translated books worldwide, having been translated to various languages, but especially into English. This is not only due to the great number of non-Arab Muslims but also because of the increasing interest in Islam as a religion in recent years.

To Muslims, the Quran is an extraordinary book revealed to the Prophet Mohammad by the archangel Gabriel - an archangel sent down by God - in the early part of the seventh century AD. The Quran consists of 114 chapters (Suras), 6,218 verses (Ayas), 77,437 words, and 321,000 letters (cited in Abdul-Raof 2003: 113). The Quran is considered as the core message of Islam and is highly respected by all Muslims, who regard it as a fundamental source of reference for the Islamic religion, its rituals, ethics, and laws. "It is the book that 'differentiates' between right and wrong, so that nowadays, when the Muslim world is dealing with such universal issues as globalization, the environment, combating terrorism and drugs, medical ethics, and feminism, evidence to support the various arguments is sought in the Quran" (Abdel Haleem 2004: ix).

Classic Arab scholars state that the word Quran, القران, is morphologically derived from one of two roots. Scholars such as Mohammad al-Rāzī, al-Farra' (cited in al-Saleh 2000), and al-Asfahani (2009) believe that the word Quran is derived from the verb قرن, as in 'collecting' 
and 'gathering', whereas other scholars, such as Al-Qattan (1990), argue that it is derived from the verb قرأ, which means 'recite' or 'read'.

Historically, Muslims and non-Muslims alike have debated on the 'untranslatability' of the Quran. While some people believe it is a holy text that cannot be translated, others pointed to the importance of providing translated versions to non-Arabs. Therefore, we can surely see the different types and the considerable variations of translations available today. For instance, some translators opted to create an explanation and commentary in addition to the Arabic text, while some translated the meaning rather than the text itself, and others tried to translate the text whilst maintaining its linguistic beauty. Fatani, who strongly opposed to the translation of the Quran, notes, "How could one possibly translate a linguistic miracle. ...". (Fatani, 2006: 657). On the other hand, Ali (2006) argues that translating the Quran is a 'moral duty', and whilst any translation of the Quran can never be an exact representation of the Quran itself, such a translation is crucial to carry the meaning into other languages. It is perhaps due to the linguistic miracles found in the Quran, as manifest in the sophisticated formation of the sentences and the use of musical sounds that create a marvellous euphony, that one can only argue how it is quite impossible to produce a translation with similar linguistic features.

Hussein Abdul-Raof - a contemporary scholar of Quran translation - states:

\begin{abstract}
Quranic discourse is a linguistic scenery characterised by a rainbow of syntactic, semantic, rhetorical, phonetic and cultural features that are distinct from other types of Arabic discourse. Through the coalition of these features, a unique linguistic texture unfolds to the reader dominated by harmony on the syntactic, semantic and prosodic levels: in fact, interfertilisation among these elements could not be better achieved. Most of these features are alien to the linguistic norms of other languages. (2004, p. 92)
\end{abstract}

He further clarifies that any translations will inevitably suffer from loss of meaning at a certain level, which is mainly due to adopting either a semantic or a communicative translation approach. Abdul-Raof claims, "A semantic translation attempts to render as closely as the semantic and syntactic structures of the target language allow, the exact contextual meaning of the source language message. A communicative translation, by contrast, attempts to produce on its readers an effect as close as possible to that obtained on the reader of the source text." (Abdul-Raof 2004:93). He further (Abdul-Raof 2003:21) stresses, "The beauty of Quran-specific language and style surpasses man's faculty to reproduce the Quran in a translated form", and thus illustrates several of the reasons that underlie the untranslatability of Quranic discourse, namely semantic, structural, and rhetorical voids. This study will mainly focus on sematic voids, which are defined as a full or partial loss of meaning or semantic proprieties during the translation process; for example, voids in translating religious or cultural terminology, voids in translating near-synonyms and voids in translating metaphor. nearsynonyms in particular was chosen because they share similar semantic proprieties that can confuse native speakers similarly to non-natives, in addition to the fact that Quranic discourse has its own lexicon that are culturally bound.

The issue of the Quran's untranslatability will be analysed throughout this article, mainly by addressing the semantic void. This is mainly because the study aims to understand both connotative and denotative meanings of pairs of near-synonyms and how they were translated into English, and further whether the translation resulted in a semantic void. This study aims to analyse three pairs of near-synonyms that have slightly different meanings yet ones that are very significant in the Quranic context they exist in. Unlike previous studies, that mainly focused on one pair of near-synonyms and how they were translated in various English translations of the Quran without any emphasis on the translations or the translator's background, this study aims to highlight both connotative and denotative meanings of the three different pairs and their translation in three different official translations of the Quran itself; and further highlights whether the translators' backgrounds influenced their translations or otherwise. Furthermore, the article aims to elaborate on the various strategies used by these translators to signify the 
difference in meaning between the pair of near-synonyms in their connotative and denotative meanings, and whether they rendered these meanings in their translations

\section{SEMANTIC VOIDS}

Arabic is known for its sophisticated and rather different linguistic features, which when translated would result on rhetorical and structural voids. Rhetorical voids are occurred when certain Arabic linguistic strategies exist like called iltifātتاتلفات . To Zamakhsharī, iltifāt is a stylistic feature that has a rhetorical effect and can be understood as the transition from addressing one person to another (in Lane, 2005). On the other hand, structural voids are seen when specific linguistic features are difficult to render with the same style and carrying the same meaning; such as alliteration, assonance and epizeuxis. Although structural and rhetorical voids share a similar importance, semantic voids can in fact change the meaning or convey it incorrectly to the target text audience.

In order for translators to translate specific lexical items, they should first process these words into their culture in an attempt to find the right equivalence in the target language. Most importantly, they should understand both the denotative and connotative meaning of these words. For instance; in translating near-synonyms certain differences can exist depending on the context these words appear in, and how they have different meanings. Certainly, some words can be easily translated into the target language; regardless of whether they carry the same connotative meaning, or mainly the denotative meaning. For instance, the word Allah “الله" when translated into 'God' loses its significant concept of oneness. It 'fades away' when replaced by God, especially given that in the Bible the word God may refer to the father, the Son and the Holy Spirit, not to mention that it can be used in a form of a plural, as in gods (Abdul-Raof, 2001).

In contrast, there are words that need proper clarification to the target language audience, since they are mainly only known and understood as concepts in the Islamic culture or in the Arab region. According to Abdul-Raof (2005:168), an example of such words is /وضو (ablution/sand ablution), which if translated to English might be seen as near-synonyms with a slight difference in the way they are performed. These cultural references are mainly understood by Muslims because they are among the rituals they are requested to do before prayer. For instance, the word وضوs - (wudu) ablution is to wash parts of the body before praying, while the word تيمم - (Tayammum) sand ablution is to perform the same ritual but with sand when water is not available.

\section{NEAR-SYNONYMS}

This article sheds light on one of the more significant features of the Quran, which is its linguistic richness and beauty. It highlights the importance of near-synonyms and their particular translations in various English translations of the Quran itself. While synonyms are defined as a semantic relation that binds two terms with the same denotative meaning that belong to the same word category but differ in form (Matulewska, 2016), near-synonyms have similar but not identical meanings and are, in fact, considered the most common type of synonyms (cited in Abdul-Ghafour, Awal, Zainudin \& Aladdin, 2019:130). Near-synonyms are defined by Cruse as lexical items whose meanings are relatively close to each other and which are sometimes difficult to differentiate between, such as fog/mist (Cruse, 2000:159). According to Cruse - who refers to near-synonyms as plesionyms - it is rather complicated to describe where near-synonymy crosses into non-synonymy. "The limits of plesionyms in the opposite direction along the scale of synonymity are more difficult to specify; as the semantic distance 
between lexical items increases, plesionyms shades imperceptibly into non-" (Cruse, 1986: 286). He further remarks that near-synonyms have two important characteristics: the first is that language users should be able to differentiate between different words and to realise which pairs are considered synonyms, and the second is the insufficiency in referring to the semantic scale, i.e., the precise differences between words' meanings (Cruse, 1986). Perhaps this is the reasons why Edmonds and Hirst (2002) argue that dictionaries cannot give the exact meaning of particular words due to the different connotations they have, and this is how near-synonyms are created. In their attempt to explain near-synonyms, Edmonds and Hirst emphasize that "Usually, words that are close in meaning are near-synonyms (or plesionyms) almost synonyms, but not quite; very similar, but not identical, in meaning; not fully intersubstitutable, but instead varying in their shades of denotation, connotation, implicature, emphasis, or register" (Edmonds and Hirst, 2002: 107).

In the Arabic language, many scholars believe that the existence of synonyms dates back to the second century after Hijra, where scholars started discussing the idea of the slight differences between words in any language (Anis, 2003). Similarly, Omar (2001:102) emphasised the existence of synonyms in both Arabic and Quranic discourse, arguing that there are two types of synonymy:

1- $\quad$ Full synonymy, where words are almost identical in their meaning. Omar (2001) demonstrates this with an example from the Quran, where the words فضل / آثر carry the same meaning:

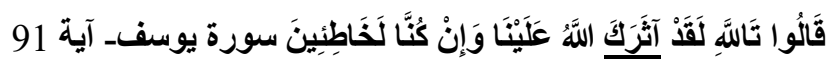

They said: By Allah! Indeed, Allah has preferred you above us, and we certainly have been (deliberate) sinners - Yusuf 12:91

$$
\text { تلك الرسل فضلنا بعضهم على بعض سورة البقرة - آية } 253
$$

Those are the messengers some of whom We have given excellence over some others. Al Baqarah 2: 253

2- $\quad$ Near synonymy, where words might have similar meanings in the language but certainly have different meanings in the Quranic discourse, such as

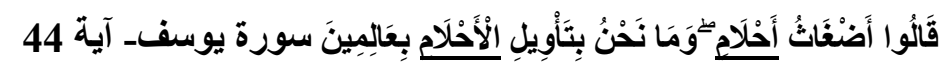

They replied, "These are confused visions and we do not know the interpretation of such dreams - Yusuf 12:44

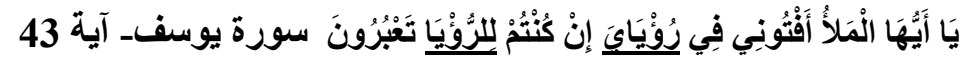

O chiefs! Tell me the meaning of my dream if you can interpret dreams - Yusuf 12:43

In this regard, Abdul-Ghafour, Awal, Zainudin \& Aladdin (2019) state that there are certain lexical items in the Quranic discourse that might appear to be full synonyms, but with a deep semantic analysis actually appear to convey different meanings. These are usually referred to by the majority of Arab Scholars as Quranic near-synonyms, and defined as lexical items that share some, but not all, shades of meaning (Omar 2001).

There have been several research efforts that have examined the connotative and denotative meanings in the Quranic discourse and that, most importantly, discuss nearsynonyms in the Quran. Among these are Abdul-Raof's (2018:109) discussion of semantic meaning, where he states:

Each lexical item in the Holy Qur'ān has its own inherent semantic componential features which can be slightly distinct from another lexical item that has its own innate semantic componential features claiming that the context and semantic componential features are the major factors in the selection of one word rather than the other. 
In a similar vein, Al-Shacrāwī (1993) argues that near-synonyms can be understood as a different phenomenon in the Quranic discourse. This is mainly due to the different nature of the Quranic Discourse has than other discourses. Al-Shacrāwī (1993) further elaborates that two words might have different meanings and cannot be used interchangeably.

In the field of Translation Studies, various scholars have attempted to study meaning and its relation to translation due to the particular impact it has on the translation process. According to Dickins, Hervey and Higgins (2002), meaning is divided into two basic types: denotative meaning and connotative meanings. They further remark that denotative meaning is the literal meaning of words, although it could mean something else when applied to figures of speech such as metaphors (Dickins, Hervey \& Higgins, 2002). Dickins, Hervey and Higgins define denotation as, "that kind of meaning which is fully supported by ordinary semantic conventions, such as the convention that 'window' refers to a particular kind of aperture in a wall roof." (Dickins, Hervey \& Higgins, 2002, p. 52). On the other hand, they define connotative meaning as various and varied, and consider aspects of meaning in addition to the denotative meaning of a lexical item and can vary depending on the context they exist in (Dickins, Hervey \& Higgins, 2002, p. 66). This is probably amongst the reasons why many translators suffer when translating Quranic verses due to the complexity of the process and the particular and rather unique context the words exist in. It does not only require an understanding of the denotative meaning but also the connotative meaning of the words in addition to the context they exist in, which evidently requires an in-depth knowledge of Islamic culture itself.

Although there has been little focus on the examination of the phenomenon of nearsynonyms and their translation in a Quranic discourse, some researchers have chosen to analyse the way these near-synonyms have been conveyed into English in various translation of the Quran. For instance, Abdellah (2010) chose to examine the way the pair ( المطر / الغيث ) is translated in five different translations based on the context they existed in, ultimately concluding that four translators did not differentiate between the pair and translated both into one English equivalent, 'rain', while only one translator chose to add adjectives in the attempt to explain what type of rain it was. Although Abdellah's examination of these five different translations is very thorough, it lacks a contemporary translation of the Quran since the five were made in 1954, 1964, 1983, 1984 and 1999. In addition, Abdellah's study mainly focuses on an understanding of near-synonyms in the contexts they exist in.

Likewise, Abbas and Al-Khanji opted for an analysis of the word pair (اسطاع/ استطاع) because they share the same root. The study chose to analyse five different translations that the authors believe to be very popular in the Muslim world. Abbas and Al-Khanji concluded that the pair were translated inconsistently and without any justification for such (Abbas and AlKhanji, 2019, p. 132). Furthermore, they emphasised that some Quranic words are untranslatable and cannot be rendered into another language. The inconsistency is perhaps based on the context these verbs exist in, and the extent of the differences between Arabic and English language norms and connections. One can argue that maintaining the same level of linguistic beauty whilst simultaneously rendering the meaning of the Quran into another language would be almost impossible, but transferring the message and rendering the meaning via a communicative approach would be rather more feasible.

On the other hand, Abdul-Ghafour, Awal, Zainudin and Aladdin (2019) aimed to examine the translation of the interplay of synonyms in Quranic discourse. They investigated the word pair الكتب - الأسفار that exhibit two semantic relations, synonymy and polysemy, and their contextual meanings in Quranic discourse and how they were translated in two English translations. Both translations are by American translators, but each of whom had different religious backgrounds, unfortunately the translators' backgrounds were not part of the analysis. The analysis conveyed the idea that there are some semantic differences between near- 
synonyms, and that these differences were not conveyed when the pair was translated into English by each of the translators.

In this study, however, I intend to analyse three different pairs that have very prominent differences in meaning. I have chosen the first pair, زوجه / امرأتثه because it has not, to date, been highlighted in any previous analysis yet has a significant difference in the Quranic discourse and has been widely discussed in the Islamic Studies discipline, particularly in Quran Exegesis. In contrast, the second pair, المطر / الغيث, has previously been examined by Abdellah but with older translations, and I would like to see if the translation approaches differed in rendering the denotative meaning in more recent translations. Lastly, the reason to examine the pair / الجسم الجسد which was translated to several different translations, is to examine whether it was translated based on the context it existed on or simply because of an inconsistency in the translation. The objectives of this study are, firstly, to highlight whether there are any semantic voids created by lack of accuracy in rendering the denotative meaning of these near-synonyms; secondly, to understand whether the translator's background can, in fact, influence their translation; and, lastly, the comparison between old and contemporary translations should highlight whether the latter are more accurate and communicative.

\section{APPROACHES TO TRANSLATING THE QURAN}

Over the years, the variety of translations of the Quran have adopted different styles and approaches. Regardless, scholars argued that the majority of the translations lack the linguistic uniqueness of its original wording. According to Fatani (2006), most translations have adopted a semantic approach, which is known in Translation Studies to focus on the textual function, in both form and content, in a similar manner to the formal equivalence. This would essentially be intended to translate solely the denotative meaning, rather than both the denotative and connotative meanings, of the near-synonyms. "Most translators aim at 'functional equivalence', where the emphasis is on communication of message at the expense of lexical equivalence" (Fatani, 2006, p. 660). In an attempt to explain the semantic approach adopted by translators, Abdul-Raof (2001) asserts that in this approach, translators adopt an archaic form of language and, for the most part, literal word order translation. An example of these translations is those by Arberry (1962), Asad (1980), and Ali (1983). These literal translations have "adopted an approach to translation that allowed the source language to have dominance over the target language" (Welch, 1990, p. 272).

Contrary to the previous approach, the communicative approach is mainly concerned with conveying the message from the Quran, and the denotative meaning of near-synonyms and what they mean in a Quranic context. Hence, translators used a communicative contemporary version of the English language instead of the archaic language used by other translators. A famous example of a communicative English translation of the Quran is The Quran - A New Translation by Muhammad Abdel Haleem in 2004.

\section{DATA AND METHODOLOGY}

This article aims to examine the phenomenon of near-synonyms in the Quranic discourse and the way they have been rendered in several of the translations of the Quran; this is simply to explore how the existing translation conveyed their meaning. In addition, it analyses the level of accuracy in translating near-synonyms in the Quran. The level of accuracy is defined in this study as the conveyance of both the connotative and denotative meaning of both nearsynonyms in a similar manner to that in the Quranic context. This analysis will enhance our understanding of the ongoing debate about the untranslatability of the Quran, in particular regarding semantic voids. Indeed, Abdul-Raof (2001) was among many scholars who argued 
that numerous translations opted for a poetic translation similar to the linguistic style of the Quran, which resulted in significant distortion of meaning. In a similar vein, Faiq believes that the array of the poetic linguistics features that distinct the Qur'anic discourse from other Arabic discourse could not be achieved (Faiq, 2004, p. 92).

The data will be extracted from three different translations: 1) The Koran Interpreted by Arthur J. Arberry in 1962, p. 2) The Quran: A New Translation by Mohammad Abdel Haleem in 2004; and 3) The Sublime Quran by Laleh Bakhtiar in 2007. There are two main reasons behind choosing these three particular translations. First, they are by people with different educational, religious, and linguistic backgrounds, for instance Arberry is a British orientalist, while Abdel Haleem is a Muslim Egyptian scholar in Islamic studies, and Bakhtiar is an American/Iranian feminist Muslim. As previously discussed, this article aims to analyse whether the translator's background has influenced their translation, their word choice, or even their understanding of both the connotative and denotative meanings of the Quran. For instance, it was often suggested that Arberry attempted to recreate the Quran with its linguistic and unique language into Arabic, bearing in mind the different linguistic styles used in the Quranic discourse. According to Siddiek "despite all his efforts, Arberry was not able to get all the truth about the Quran, but he confirmed his belief that the Quran represented a literary masterpiece unparalleled in its literature of the whole world." (Siddiek, 2018, p. 48). By contrast, Abdel Haleem studied and memorised the Quran his entire life with the purpose of creating a simple English version of an interpretation of the Quran for English speakers. Shah praised Abdel Haleem's translation stating "No other translator of the Holy Qur'an has such mastery of both languages" (Shah, 2010, p. 4). Bakhtiar was the first American woman to translate the Quran, and her translation took a female perspective; however, it was also intended to create an understanding between Muslims and non-Muslims. It was quite clear that Bakhtiar's translation was influenced by her feminist background in translating some verses in the Quran (Maliki, 2001), and thus it was important and of significant interest to see how she

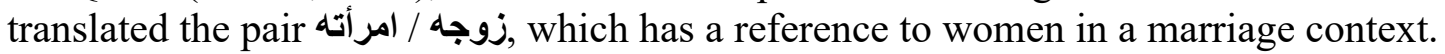

Second, each translation has been characterised differently: Arberry's as linguistically rich that copies the same linguistic beauty found in the Quran; Abdel Haleem's as the communicative and clear interpretation of the Quran; and, finally, Bakhtiar's, as the contemporary translation from a feminist perspective.

In order to understand how near-synonyms were translated and whether they were accurately conveyed in these different translations, I choose three main pairs of near-synonyms and their translations in the three given translations. As previously mentioned, the pairs are (الجسم / الجسد/ المطر / الغيث/ زوجه / امرأته differences between the two words in each pair, and because of the immense differences in the translations, as I have previously clarified. The data are first explained with regard to the Quranic discourse in which they exist, and later a comparison of how they were translated is given. The aim of the comparison is to demonstrate that translating the Quran can frequently mean elaborating and translating an interpretation rather than trying to mimic its style and linguistic features.

\section{TRANSLATING NEAR-SYNONYMS IN THE QURAN}

This section will demonstrate how near-synonyms are translated into the three mentioned translations. This is to understand how near-synonyms were perceived by the translators, and how they translated them by analysing the denotative and connotative meanings of the nearsynonym in the source and target texts. 


\section{1. نوجه / امرأته}

As mentioned before, near-synonyms have slight differences of meaning that are barely noticeable to most readers. To demonstrate this further, we need to first understand the meaning of each word in the Quranic context it existed in. The word زوجه refers to a perfect pair and an equal relationship between a man and his wife, whereas the word مرجها (196) is only used to refer to an unequal relationship. Both the Majma' al-Lughah al-'Arabiyah (1969) and Lisān al- 'Arab (Ibnur Manzur, 1968) dictionaries define the word زوج

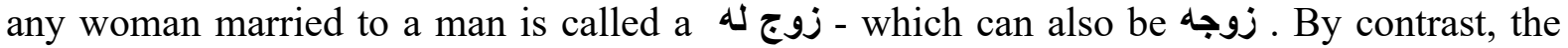

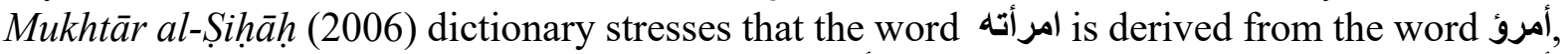
which means a human being. Therefore, the word امرأه is the feminine form of the word أمرؤ ing the and امرأته indicates a women's relationship with a man, i.e., someone's wife.

According to the Arabic -English Dictionary of Quranic Usage (Abdel Haleem \& Badwai 2008, p. 406) and The Dictionary and Glossary of the Quran (Penrice, 2006, p. 98), both define the word زوج as "the dual, wife, husband, and spouse", which is an individual being with another, in which they are united. On the other hand, the word إمراه is defined as a woman. In this regard, al-Asfahani (2009) states that the word زوج can be seen as an equal pair, unlike امرأته , which might lose the connotation of equality. In his explanation, al-Asfahani (2009)

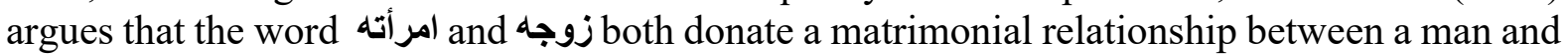
women in the Quranic discourse; however, each word has a different connotation. He further explains the in the Quran, the word زوجه is only mentioned in reference to an equal relationship between a husband and a wife, whether in religion or age, while the word امرأتها is used to refer to an unequal marriage, or one with an 'unbeliever' wife. The examples below demonstrate how this pair was translated by each of the three translators.

Tوجه TABLE 1. Translation of the word

\begin{tabular}{|c|c|c|c|}
\hline Bakhtiar & Abdel Haleem & Arberry & ST - al-Baqarah 2:35 \\
\hline $\begin{array}{c}\text { Inhabit the Garden, you and } \\
\text { your spouse }(2007, \text { p. } 6)\end{array}$ & $\begin{array}{l}\text { We said, 'Adam, live with } \\
\text { your wife in this garden' } \\
(2004, \text { p. } 7)\end{array}$ & $\begin{array}{l}\text { And We said, 'Adam, } \\
\text { dwell thou, and thy wife, } \\
\text { in the Garden' (1962, p. } \\
5 \text { ) }\end{array}$ & 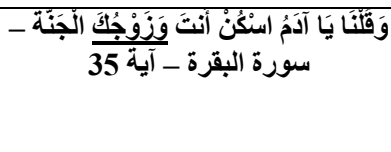 \\
\hline
\end{tabular}

TABLE 2. Translation of the word امرأته

\begin{tabular}{|c|c|c|c|}
\hline Bakhtiar & Abdel Haleem & Arberry & ST - at- Tahreem 66:10 \\
\hline $\begin{array}{l}\text { God has propounded an } \\
\text { example for those who were } \\
\text { ungrateful like the wife of } \\
\text { Noah and the wife of Lot. } \\
(2007, \text { p. } 655)\end{array}$ & $\begin{array}{l}\text { God has given examples of } \\
\text { disbelievers: the wives of } \\
\text { Noah and Lot }(2004, \text { p. } 338)\end{array}$ & $\begin{array}{l}\text { God has struck a } \\
\text { similitude for the } \\
\text { unbelievers -- the wife of } \\
\text { Noah, and the wife of } \\
\text { Lot; }(1962, \text { p. } 228)\end{array}$ & 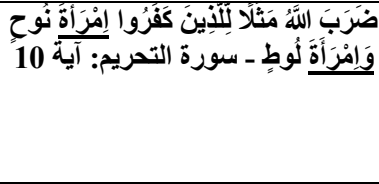 \\
\hline
\end{tabular}

As noted in the tables above, both Arberry and Abdel Haleem used the word 'wife' to translate both near-synonyms, regardless of the slightly different connotation each word has. Perhaps the reason why the word امرأته was not translated literally to 'his woman' is due to the incorrect connotation it might have since there is no form of relationship outside the frame of marriage in Islam. It seems likely that Arberry's goal to reproduce a poetic English version of the Quran made him focus on linguistic beauty rather than exact meaning. Yet one cannot argue that Arberry's different background - being non-Muslim or Arab - may have influenced this particular translation since even Abdel Haleem opted for the word 'wives', regardless of the known Quranic interpretation of the differences between this pair of near-synonyms. I would argue that Abdel Haleem's intention to simplify the Quran affected his word choice, and he thus chose to translate both words to what they represent in English regardless of their different meanings in the Quranic discourse. Unfortunately, in both translations, the connation 
of inequality intended in the Quranic discourse of both words has been lost, leading to a semantic void despite the existence of other equivalences such as: 'spouse' or 'partner'.

In contrast, Bakhtiar makes a distinction in her translation between زوجه / امرأته ' ' زوجه, as she translates the word زوجه using the English equivalent spouse in the majority of cases, while translating the word مرأته زوجه into wife. I believe that Bakhtiar's translation stands out since she chose to use the literal meaning of the word زوج as in a pair that has the sense of equality, and translated the word زوجه into spouse, whereas she translated the word مرجأته into 'his wife'. I would argue that to Bakhtiar, understanding the differences in this context in particular is rather significant due to her feminist background. To further explain, Bakhtiar mainly used the word wife to refer to what has been highlighted as a married woman, yet used the word spouse to indicate that the word might be a reference to both men and women.

\section{2. المطر / الغيث}

In the Arab region, the word مطر is often used to refer to rain, whilst the most likely use of غيثر would be specifically to refer to rain after a period of drought. The word غيث the stem غوت, which originally means to save. This is especially true since in the Arab region, rain usually only comes after a long period of drought. According to the Mu'jam al-Wajiz (1969) dictionary, the word غيث can be defined as the rain of mercy that comes from God after months of drought. Similarly, Lane remarked that the word غيث is the rain that brings a lot of good with it (Lane, 1968, p. 2314).

With regard to the word مطر, Abdellah (2010) believes that Arab lexicographers agreed that it means any type of water coming from the sky. al-Asfahani (2009) further explains that using the word مطر in Quranic discourse simply means the rain, while the word the verb of the noun مطر meaning a "punishing rain". Hence, using the word مطر can have a negative connotation in Quranic discourse, unlike the positive connotation the word غيث has. (Abdellah, 2010: , p.). Consider the following translations of both words in the tables below:

المطر TABLE 3. Translation of the word

\begin{tabular}{|c|c|c|c|}
\hline Bakhtiar & Abdel Haleem & Arberry & ST - al-A'raf 7:84 \\
\hline $\begin{array}{l}\text { And when We rained down a } \\
\text { rain on them so look how had } \\
\text { been the Ultimate End of the } \\
\text { ones who sin }(2007, \text { p. } 183)\end{array}$ & $\begin{array}{l}\text { And We showered upon [the } \\
\text { rest of] them a rain [of } \\
\text { destruction]. See the fate of } \\
\text { the evildoers }(2004, \text { p. } 100)\end{array}$ & $\begin{array}{l}\text { And We rained down } \\
\text { upon them a rain; so, } \\
\text { behold thou, how was the } \\
\text { end of the sinners! (1962, } \\
\text { p. 181) }\end{array}$ & 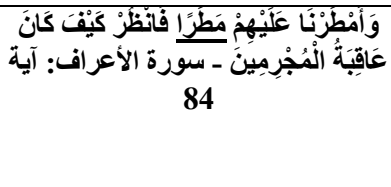 \\
\hline
\end{tabular}

TABLE 4. Translation of the word الغيث

\begin{tabular}{|c|c|c|c|}
\hline Bakhtiar & Abdel Haleem & Arberry & ST - Ash-Shūrā 42:28 \\
\hline $\begin{array}{l}\text { And He it is Who sends } \\
\text { down plenteous rain water } \\
\text { after they have despaired, and } \\
\text { unfolds His mercy. And He is } \\
\text { The Protector, The Worthy of } \\
\text { Praise. (2007, p. 564) }\end{array}$ & $\begin{array}{l}\text { it is He who sends relief } \\
\text { through rain after they have } \\
\text { lost hope, and spreads His } \\
\text { mercy far and wide. He is the } \\
\text { Protector, Worthy of All } \\
\text { Praise. (2004, p. } 313)\end{array}$ & $\begin{array}{l}\text { And it is He who sends } \\
\text { down the rain after they } \\
\text { have despaired and He } \\
\text { unfolds His mercy; } \\
\text { He is the Protector, the } \\
\text { All-laudable. (1962, p. } \\
\text { 195) }\end{array}$ & 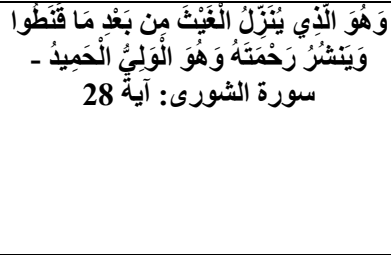 \\
\hline
\end{tabular}

It is noticeable that in translating both words المطر / الغيث translators chose a variety of words and sometimes combined the word rain with an adjective to describe its connation. For instance, Arberry choose to translate both words to rain, regardless of their negative or positive connotation, which eventually led to a loss of meaning and the importance of differentiating between a saving or punishing rain. Due to Arberry's cultural background, I believe that, for him, the use of the word rain maintained the meaning of the word الغيث, which simply signifies rain. In addition, unlike Arabic where words have many synonyms and near-synonyms; 
English, by contrast, is rather simpler and probably the reason why Arberry did not choose to differentiate between this pair of near-synonyms.

With regard to Abdel Haleem's translation, this was rather fruitful since he opted for more than one equivalent to represent this pair of near-synonyms. The words were mainly translated in the context they existed in; thus, الغيث was translated as rain and a relieving rain to demonstrate that this type of rain is a gift from God and not otherwise. As highlighted above, Abdel Haleem chose to explain the meaning of the word by restructuring the sentences it existed in using a different structure 'sends relief through rain', where he added an adjective to the word rain المطر/, such as 'dreadful, destruction, heavy and terrible' to further emphasise the negative connotation behind the word and its usage in that context. This can be clearly noticed as one of Abdel Haleem's strategies to highlight the difference between these words. I believe that Abdel Haleem's understanding of Islamic culture, its discourse, and the Arabic language and its culture, helped here with regard to rephrasing the sentences into better structured sentences in English. Most importantly, Abdel Haleem maintained the meaning of the pair and rendered this to the target text audience in an accurate manner.

Likewise, this method was also used by Bakhtiar who added adjectives to describe the connotation intended. For example, she added the word plenteous to describe the good rain الغيث, and sometimes used the word evil to refer to the rain that comes with punishment. Bakhtiar did not, however, convey the connotative meaning of the word مطر in all its occurrences as seen above, but only used the phrase 'evil rain' three times because one verse used ' مطر السوء' in the Arabic verse in the Quran, while the other highlighted the punishments that come with the rain. It can be argued that, to Bakhtiar, her goal was to create an understanding between Muslims and non-Muslims, which was the reason why she attempted to recreate the linguistic beauty and yet maintain the connotative meaning of these nearsynonyms in the Quranic discourse.

\section{3. الجسم / الجسد}

Corresponding to the previous examples, the pair الجسم/ الجسد / الجسد are among the various nearsynonyms found in the Quranic discourse. According to the al-Muhit dictionary, the word الجسم and الجسد can be both defined analogously to the human body with its organs (Abādī, 2007, p. 240). Nevertheless, al-Asfahani (2009) argues that both words have different meanings in Quranic discourse, while the word جسم was used twice to refer to live human bodies, and the word الجسد to dead human bodies. Dawood (2008) further claims that there is a precise meaning behind each word, since the word الجسد denotes the body with a soul, while the word الجسم means the body without a soul. This pair is examined through the following examples:

TABLE 5. Translation of the word الجسم

\begin{tabular}{|c|c|c|c|}
\hline Bakhtiar & Abdel Haleem & Arberry & ST - al-Anbiya 21:8 \\
\hline $\begin{array}{l}\text { And We made them not } \\
\text { bodies that ate not food, nor } \\
\text { had they been ones who will } \\
\text { dwell forever }(2007, \text { p. } 373)\end{array}$ & $\begin{array}{l}\text { We did not give them bodies } \\
\text { that ate no food, nor were } \\
\text { they immortal }(2004, \text { p. } 203)\end{array}$ & $\begin{array}{l}\text { Nor did We fashion them } \\
\text { as bodies that ate not } \\
\text { food, neither were they } \\
\text { immortal }(1962, \text { p. } 170)\end{array}$ & 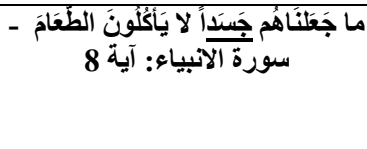 \\
\hline
\end{tabular}

الجسد TABLE 6. Translation of the word

\begin{tabular}{|c|c|c|c|}
\hline Bakhtiar & Abdel Haleem & Arberry & ST - al-Baqarah 2:247 \\
\hline $\begin{array}{l}\text { He said Truly God has } \\
\text { favoured him over you and } \\
\text { has increased him greatly in } \\
\text { knowledge and physique.; } \\
(2007, \text { p. } 45)\end{array}$ & $\begin{array}{l}\text { He said, 'God has chosen him } \\
\text { over you, and has given him } \\
\text { great knowledge and stature. } \\
(2004, \text { p. } 28)\end{array}$ & $\begin{array}{l}\text { He said, 'God has chosen } \\
\text { him over you, and has } \\
\text { increased him broadly in } \\
\text { knowledge and } \\
\text { body. }(1962, \text { p. } 63)\end{array}$ & 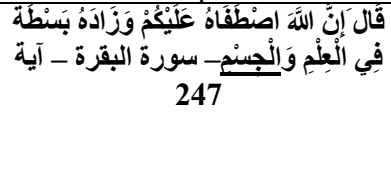 \\
\hline
\end{tabular}


/الجسد As seen in the tables above, Arberry chose one equivalent to translate both words regardless of the different connotation each word had in the Quranic discourse and created a semantic loss. One can argue that regardless of Arberry's knowledge of the Arabic language and Islamic Studies, he mainly attempted to render a purely linguistic meaning rather than examine the words in the Quranic context they existed in. Siddiek explains the reason behind the errors in Arberry's translation stating "due to the fact that the translator was genuinely not Arab, so he might misunderstand the meaning of a certain word or phrase in its literal sense, or he might not realize the meaning of some of the Quranic expressions" (Siddiek, 2018, p. $53)$.

In a relatively different attempt, Abdel Haleem's translation was mainly dependent on the context a given word existed in, hence each word was translated differently based on the sentence it was in. For instance, the word الجسم, which signifies a living human body, was translated into appearance and stature, while the word الجسد - a dead body - was translated to body, shape, skeleton, and image. Abdel Haleem's religious and cultural background has surely assisted him in understanding both connotative and denotative meanings and, later, in the translation process. This is probably the reason why he chose different words to convey the meaning based on the context the near-synonym appeared in. Abdel Haleem's extensive knowledge of both English and Arabic Language as well as Islam and the Quranic language, in addition to his goal of creating a simple and reader-friendly translation of the Quran has influenced his word choice and the way he rephrased his sentences.

Bakhtiar's translations often employ a different strategy to convey the meaning in each linguistic item. In this example, Bakhtiar demonstrated the difference between this pair by referring to each word with one significant equivalent. She uses the word physique to render the word الجسم to refer to living human bodies, and the word body in reference to الجسد, i.e., dead human bodies. In this analysis, it is clearly evident that Bakhtiar has distinguished or to some extent attempted to draw attention to the difference between the pair of near-synonyms. It is due to Bakhtiar's feminist background, her attempt to translate the Quran was to create a more readable version that does not use ambiguous words or phrases that may create confusion, by using a clear scientific methodology rather than religious interpretations that might be bias. She also believed that it is rather important for non-Arabs Muslims -like herself- to be able to understand the Quran and read it in a simple language (Khan, 2018:6). It can be argued that for that particular reason, Bakhtiar used several strategies to render meaning by either choosing a pair of equivalents to render the near-synonyms, or by adding a descriptive adjective to describe the connotative meaning and hence distinguish between the near-synonyms.

\section{CONCLUSION}

Among the various linguistic strategies, the Quran is famous for employing synonyms and near-synonyms to emphasize meaning. As previously discussed, near-synonyms are words that have different connotations and can vary in meaning. The subtle and complex meanings of such words are often difficult to translate, which is the reason why many scholars argue that translating both the denotative and connotative meaning of Quranic discourse into a clear English translation is essentially impossible.

This study finds that the translators use different approaches to render the meanings of these near-synonyms. Arberry, Abdel Haleem, and Bakhtiar all attempted to draw the attention to the subtle differences in meanings between the near-synonyms in some cases, yet not at all times. In their approach to translate the near-synonyms, the translators chose to translate the pair with two different words, or simply by adding an adjective to distinguish the differences between both words. This approach has been used in translating the pair المطر / الغيث, where 
Arberry, Abdel Haleem and Bakhtiar added a negative adjective such as 'evil/heavy/destruction' to the word 'rain' to emphasis the negative connotative the word rain has in the Quranic discourse, unlike the translation of the word الغيث, which carries a positive meaning and signifies relief and good. For instance, Arberry opted to add an explanatory adjective to the word المطر 'evil rain' to emphasis the punishment that comes with the rain, while translating الغيث simply to 'rain', leading many scholars to argue that his translation lacked precision and accuracy. By comparison, Abdel Haleem opted for easy-to-read English translations yet wanted to capture the meaning of each word and convey it correctly to the reader. Hence, in translating the word المطر , Abdel Haleem described it using different adjectives based on the context the word existed in, such as 'destruction, dreadful, heavy, and terrible rain', which was to emphasis the type of rain and the punishment that comes with it. Abdel Haleem clearly used to describe the near-synonyms to distinguish them from each other and based on the context they existed in. Likewise, Bakhtiar differentiated between the pair by only adding the word 'evil' to translate المطر.

Regardless of the different attempts and approaches used by the three translators to translate the near-synonyms and differentiate between them, one may note that both Arberry and Abdel Haleem failed to distinguish between the near-synonyms زوجه / امرأته . Both translators chose one equivalent - the word wife - to translate the pair of near-synonyms. Although the word wife does in fact signify the right meaning in a general sense, it does not necessarily have the same precise connotative meaning as the associated Quranic discourse. Therefore, their translation lacked accuracy in translating this pair and eventually lost an important element of the overall meaning and created a semantic void. By contrast, Bakhtiar recognised the difference between the pair امراته /زوجه and translated them differently. She captured an accurate meaning by translating each word with one specific equivalent. In her translation, she used the word 'spouse' to translate زوجراته 'موجه whereas she translated the word into the word 'wife'. I believe that the use of the word 'spouse', in particular, refers to the sense of equality the word زوجه has, unlike the word 'wife' which merely refers to a wife in translating the word مراته

From the data examined, it is evident that each translator chose their own approach based on their translational goal or their educational and personal backgrounds. While some chose a semantic approach and essentially translated only the denotative meaning, others opted for a communicative approach and attempted to distinguish between these near-synonyms and their conative meanings in the Quranic discourse. Translators often focus on the precise meaning and accuracy of the source text and how to convey this meaning in a rather understandable and acceptable way into the target text. This is especially true in dealing with religious and archaic forms of language that might be hard to understand and even harder to translate to other languages. Hence, one can notice that translators frequently add a description to the word they aim to convey its meaning, especially when there are no similar equivalences in the target language.

Without doubt, translating the Quran is a rather challenging task for translators due to its linguistic complexity in combination with its linguistic beauty. The above analysis has proven the difficulty and perhaps the impossibility of translating the Quran without any voids, whether semantically or linguistically. This leads us back to the untranslatability of the Quran in general, though probably the difficulty rather than the unfeasibility of the attempt. I certainly believe that translating the Quran is a rather impossible task, but creating an appropriate interpretation of it is surely achievable. This is not only because of the linguistic barriers, but also the rhetorical ones. There are various linguistic tools that are hard to render; thus, many translators chose to translate the meaning of the Quran whilst neglecting its rhetorical devices and linguistic beauty, creating a rather 'ordinary' discourse, whilst many others have opted for a poetic style that created an awkward style in English and a very difficult discourse to read. 
In this study, the analysis of the near-synonyms and their English translations are shown to create semantic voids in some cases. The difficulty in finding the proper translation semantically is mainly one of the many obstacles and challenges translators face when translating the Quran.

\section{REFERENCES}

Abādī, E. (2007). Al-Qamus al-Muhit. Beirut: Dār AlKutb.

Abdel Haleem, M. (1992). 'Grammatical Shift for Rhetorical Purposes: Iltifat and Related Features in the Quran', Bulletin of the School of Oriental and African Studies. 55(3), 407-432.

Abdel Haleem, M. (2004). The Qur'an: A New Translation, Oxford University Press. Oxford.

Abdel Haleem, M. and Badwai, M. (2008). Dictionary of Quranic Usage, E.G Brill.

Abdellah, A. (2010) Translation of Near-Synonyms in the Quran. VDM Publishing House Ltd. Germany.

Abdelwali, M. (2007). 'The Loss in the Translation of the Quran'. Translation Journal. [e-journal] Vol.11, 2. Available at $<\underline{\text { http://accurapid.com/journal/40quran.htm }}>$, [Accessed 13 September 2020].

Abdul-Ghafour, A. Q. K. M., Awal, N. M., Zainudin, I. S., \& Aladdin, A. (2019). The Interplay of Qur'ānic Synonymy and Polysemy with Special Reference to Al-asfār and Al-kutub (the Books) and their English Translations. 3L: Language, Linguistics, Literature ${ }^{\circledR}, 25(1)$.

Abdul-Raof, H. (2001). Quran Translation: Discourse, Texture and Exegesis, Curzon Press, Richmond.

Abdul-Raof, H. (2003). Exploring The Quran. al-Maktoum Institute Academic Press. United Kingdom.

Abdul-Raof, H. (2004). 'The Quran: Limits of Translatability', in Said Faiq(ed.) Cultural Encounters in Translation From Arabic, Clevdon, Buffalo, Toronto, Multi Lingual Matters Ltd.: 91-106.

Abdul-Raof, H. (2005). 'Cultural Aspects in Quran Translation', in Lynne Long (ed.) Translation and Religion: Holy Untranslatable? Clevdon, Buffalo, Toronto, Multi Lingual Matters Ltd.: 162-172.

Abdul-Raof, H. (2018). Text Linguistics of Qur'anic Discourse: An Analysis. Routledge.

Al-Abbas, L., \& Al-Khanji, R. (2019). Near-Synonyms Within the Same Qur'anic Verse: A Contrastive EnglishArabic Lexical Analysis. International Journal of English Linguistics, 9(6).

Al-Asfahani, A. (2009). Mufrādat Al-Alfāth Al-Qur'ān. Damascus: Dār Al-Qalam.

Al-Qattan, M. (1990). Mubāhth fe Olum Al-Qur'ān. Cairo: Wahba Bookshop.

Al-Rāzī, M. (2006). Mukhtār al-Ṣiḥāḥ (6th edition). Beirut: Dār al Fayha.

Al-Saleh, S. (2000). Mubāhth fe Olum Al-Qur'ān. Beirut: Dār El Ilm Lilmalayin.

Al-Shacrawī, M. M. (1993). Mucjizāt Al-Qur'ān. Cairo: Bookshops and Books Management.

Al-Zamakhsharī, A. (2009). Al-Kash-shāf can Haqāiq Ghawāmiḍ Al-Tanzīl. Beirut: Dār Al-Macrefah.

Ali, A. Y. (1983). The Holy Qur'an: Text and Translation. The Other Press.

Ali, M. (2006). 'Word Repetition in the Quran-Translating form or meaning?' Language \& Translation. 19. 1734.

Anis, I. (2003). Fi Al-lahjat Al-Arabyiah. Cairo: Anglo Egyptian Library.

Arberry, A. (1962). The Koran Interpreted. George Allen \& Unwin, London.

Asad, M. (1980). The message of the Qur'an. Dar al-Andalus.

Bakhtiar, L. (2007). The Sublime Quran. Library of Islam. Chicago

Blankinship, K. (2019). The Inimitable Qurn Some Problems in English Translations of the Quran with Reference to Rhetorical Features. Brill

Cruse, A. (1986). Lexical Semantics. Cambridge University Press, Cambridge.

Cruse, A. (2000). Meaning in Language: An introduction to Semantics and Pragmatics. Oxford University Press, Oxford.

Dawood, M. (2008). Mu'jam Al-fouroq Al-dalalyiah fi Al-Qur'ān Al-Karìm. Cairo: Dār Gharib for Printing and Publishing

Desilver, D. (2013), World's Muslim Population More Widespread than You Might Think. Washington: Pew research center. Retrieved 3 October ,2020 from http://www.pewresearch.org/facttank/2013/06/07/worlds-muslimpopulationmore-widespread-than-you-might-think/

Dickins, J., Hervey, S., and Higgins, I. (2002). Thinking Arabic Translation. Routledge, London and New York. Edmonds, P. \& Hirst, G. (2002). Near-synonymy and lexical choice. Computational Linguistics, 28(2), 105-145. Faiq, S. (Ed.). (2004). Cultural Encounters in Translation from Arabic (Vol. 26). Multilingual Matters.

Fatani, A. (2006). 'Translation and the Quran', in Oliver Leaman (ed.) The Quran: an encyclopedia, Routledge, London and New York.

Ibn- Manzur (1968). Lisān al- 'Arab. Beirut: Dār Al-Arab.

Khan, S. (2018). Laleh Bakhtiar's Eligibility to Be a Qur'an Translator and Her Methodology of Translating It into The English (Master's thesis). Qatar University. 
Lane, A. (2005). A Traditional Mu'tazilite Qur'ān Commentary: The Kashshāf of Jār Allāh al-Zamakhsharī (d. 538/1144). Brill.

Lane, E. (1968). An Arabic- English Lexicon. Riad el-Solh Square.Lebanon

Majma' al-Lughah al-'Arabiyah. (1969). Mu'jam al-Wajiz. Egypt: Maktabat al-Shuruq al-Dawliyah.

Maliki, N. (2001). Translating Hijab Verse in the Quran by Women: A Feminist Perspective. Hamad bin Khalifa University, Qatar.

Matulewska, A. (2016). Semantic relations between legal terms: a case study of the intralingual relation of synonymy. Studies in Logic, Grammar and Rhetoric. Vol. 45 (58), 161-174.

Mustapha, H. (1998). 'Quran (Koran)'. In Mona Baker (ed.), Routledge Encyclopedia of Translation. Routledge, London and New York.

Omar. A. M. (2001). Drasat Lughawyah fi Al-Qur'ān Al-Karīm wa Qirā'atih. Cairo: cĀlam Al-Kutub.

Penrice, J. (2006). A Dictionary and Glossary of the Quran. The Other Press. Kuala Lumpur.

Robinson, N. (1996). Discovering the Quran: A Contemporary Approach to a Veiled Text. London: SCM Press.

Rodwell, R. (1861) The Koran Translated from the Arabic. J M Dent \& Sons: London and Toronto.

Shah, M. S. (2010). A critical study of Abdel Haleem's new translation of the Holy Qur'an. Al Qalam, 1, 1-15.

Siddiek, A. G. (2018). A Critical Reading of AJ Arberry's Translation of the Meanings of the Holy Quran (Koran Translated). International Journal on Studies in English Language and Literature (IJSELL), 6(5).

Welch, T. (1990). 'The translatability of the Quran: literary and theological implications of what the Quran says about itself'. In David M. Goldenberg (ed.) Translation of Scripture; pp. 249-285. 